\title{
Child Immunization Coverage of Some Rural Belt in Relation to Socio-economic Factors of Jalpaiguri and Darjeeling District of West Bengal
}

\author{
Prabir Kumar Manna ${ }^{1}$, Kausik Chatterjee², Debasis De ${ }^{2}$ and Debidas Ghosh* \\ ${ }^{1}$ Department of Physiology, Siliguri College, Siliguri, Darjeeling, West Bengal, India \\ ${ }^{2}$ Department of Bio-Medical Laboratory Science \& Management, \\ Vidyasagar University, Midnapore 721 102, West Bengal, India
}

KEYWORDS Children. Vaccination. Dropouts. Diseases. Mortality. North Bengal

\begin{abstract}
The present study aimed to assess the immunization coverage, prevalence of diseases and child mortality of Jalpaiguri and Darjeeling Districts of West Bengal . A cross sectional study was performed on 1748 families that covered 1148 boys and 1116 girls at different blocks of Jalpaiguri and Darjeeling Districts of West Bengal . The study was made by different pre structured questioners to know the education level of parents, immunization knowledge, diseases susceptibility, child mortality etc. The immunization coverage was identified by checking the immunization card and questioners. The result showed that the immunization against Bacillus Calmette Guerin (BCG), Diphtheria, Pertussis and Tetanus (DPT), Polio and Measles coverage in the study area is much lower than the national coverage level. The BCG coverage is $81.36 \%$ for boys and $80.65 \%$ for girls. The DPT coverage is $61.06 \%$ and $61.92 \%$ for boys and girls respectively. The polio coverage for boys is $61.32 \%$ and for girls is $63.17 \%$. The measles coverage for boys is $53.75 \%$ and for girls is $52.24 \%$. We found that $49.25 \%$ parents produced immunization card. The rural mothers having low immunization knowledge. Disease susceptibility and mortality rate of the children are also high. Proper steps should be taken from the government side to change the attitude and practices and to improve the knowledge and awareness for better immunization and coverage.
\end{abstract}

\section{INTRODUCTION}

Universal Immunization Programme (UIP) was introduced in India in 1985-86 for complete immunization of the children. The Reproductive and Child Health Programme (RCH) was launched in October 1997 and it aims was to universalize the immunization, antenatal care etc. The RCH phase II was introduced while forming a part of the $\mathrm{X}^{\text {th }}$ plan which was based on lessons learnt from RCH phase- I.

The World Health assembly resolved to eradicate poliomyelitis from the world by the year 2000 AD reported by Grachev (1994).

The immediate objective of RCH-II, as envisioned in National Population Policy (NPP) 2000 , is to achieve universal immunization of children against all vaccine preventable disease by 2010 reported by Ministry of Health and Family Welfare (1999). To achieve the goal universal immunization has introduced in every district of

*Corresponding author:

Dr. Debidas Ghosh, Professor \& Head

Department of Bio-Medical Laboratory Science

\& Management, Vidyasagar University

Midnapore 721102 , West Bengal

E-mail: debidas_ghosh@yahoo.co.in our country. Inspite of the UIP several reports like Lodha et al. (2000) focused that the prevalence of diphtheria in North India is also high. According to Dalal et al. (2005) the fully immunized children in Goa is not up to the satisfactory, though the importance of universal implementation of BCG vaccination in Kerala as per Pulickal et al (2007) is also good .

People of North Bengal are comparatively illiterate and poor workers. Both the parents need to go for hard work everyday to earn money for the feeding of their family member including children. They do not have the time and knowledge to understand the other essential elements of life like education, immunization etc. Keeping this in mind we wanted to see the immunization status of the children of economically poor class of Darjeeling and Jalpaiguri districts, West Bengal.

\section{Experimental Design}

A cross sectional study was conducted in the two districts of North Bengal (Darjeeling and Jalpaiguri) between December 2006 - March 2008. From these two districts 1768 families were selected randomly for data collection. We got 1148 
boys and 1116 girls of 1 to 7 years of age from the selected families. We collected the information to assess the immunization coverage with the evaluation of child immunization card and parents interview. We also tried to find out the reasons for non-immunization, dropouts, disease susceptibility and the mortality of children. To know the knowledge of parents about child immunization, we made a score table where 0.25 score was allotted for the name of the vaccine, 0.25 score for the doses of the vaccine, 0.25 score for the time schedule and 0.25 score for the function of the vaccine. In that way 1(one) mark is given for one vaccine. As we considered four vaccines (BCG, DPT, Polio and Measles) so the highest score will be four

\section{OBSERVATION}

We collected 2264 children from the 1768 families. Table 1 is showing the distribution of boys and girls according to their age.

Both father and mother from 313 families out of 1768 families were participated in our study and included to know the education level. We found that $25.95 \%$ father and $30.96 \%$ mother are illiterate out of the study area. About $3 \%$ fathers and about $7 \%$ mothers have education up to class-X or above. The number in percentage of illiterate and primary educated father is $65.49 \%$ and mother is $67.45 \%$ (Table 2).

We found that $18.64 \%$ boys and $19.35 \%$ girls

Table1: Age wise distribution of boys and girls.

\begin{tabular}{lrrr}
\hline Age (year) & Boys & Girls & Total \\
\hline $1-2$ & 197 & 199 & 396 \\
$2-3$ & 185 & 202 & 387 \\
$3-4$ & 227 & 206 & 433 \\
$4-5$ & 193 & 185 & 378 \\
$5-7$ & 346 & 324 & 670 \\
\hline Total & 1148 & 1116 & 2264 \\
\hline
\end{tabular}

Table 2: Education level of parents in the study zone.

\begin{tabular}{lrrrrr}
\hline Education Level & \multicolumn{2}{c}{ Father } & & \multicolumn{2}{c}{ Mother } \\
\cline { 2 - 3 } \cline { 5 - 6 } & No. & $\%$ & & No. & \multicolumn{1}{c}{$\%$} \\
\hline Illiterate & 170 & 25.95 & & 442 & 30.96 \\
Primary & 259 & 39.54 & & 520 & 36.47 \\
Class V-VIII & 138 & 21.06 & & 228 & 15.99 \\
Class IX-X & 69 & 10.53 & & 178 & 12.48 \\
Class XI-XII & 13 & 1.98 & & 43 & 6.56 \\
Class above XII & 6 & 0.92 & & 15 & 1.05 \\
\hline Total & 655 & & 1426 & \\
\hline
\end{tabular}

did not-receive of BCG vaccine. Only $81.36 \%$ boys and $80.65 \%$ girls were immunized with BCG (Table 3). This indicates slightly lower coverage of BCG vaccination in the two districts as compared to North East (NE) states coverage (BCG-84.1\%) studied by Yadav and Singh (2004) as well as to national coverage (BCG-85.9\%) studied by Singh and Yadav (2000) .

The table (Table 4) of DPT focused that $18.82 \%$ boys and $16.22 \%$ girls were not immunized with DPT vaccine. The value of partially immunized with DPT were $20.12 \%$ for boys and $21.86 \%$ for girls. So, the combined numbers of non-immunized and partially immunized for boys and girls were $38.94 \%$ and $38.08 \% .61 .06 \%$ boys and $61.92 \%$ girls were fully immunized with DPT. The coverage with DPT vaccine of the two districts

Table 3: Immunization status of BCG.

\begin{tabular}{lccccc}
\hline \multirow{2}{*}{$\begin{array}{l}\text { Age } \\
\text { (year })\end{array}$} & \multicolumn{2}{c}{ Boys } & & \multicolumn{2}{c}{ Girls } \\
\cline { 2 - 3 } \cline { 5 - 6 } & $\begin{array}{c}\text { Non- } \\
\text { imminized }\end{array}$ & $\begin{array}{c}\text { Immu- } \\
\text { nized }\end{array}$ & & $\begin{array}{c}\text { Non- } \\
\text { immunized }\end{array}$ & $\begin{array}{c}\text { Immu- } \\
\text { nized }\end{array}$ \\
\cline { 2 - 3 } \cline { 5 - 6 } & No. & No. & & No. & No. \\
\hline $1-2$ & 34 & 163 & & 37 & 162 \\
$2-3$ & 37 & 148 & & 34 & 168 \\
$3-4$ & 41 & 186 & & 42 & 164 \\
$4-5$ & 38 & 155 & & 39 & 146 \\
$5-7$ & 64 & 282 & & 64 & 260 \\
\hline Total & 214 & 934 & 216 & 900 \\
& $(18.64)$ & $(81.36)$ & $(19.35)$ & $(80.65)$ \\
\hline
\end{tabular}

Table 4: Immunization status of DPT.

\begin{tabular}{|c|c|c|c|c|c|c|}
\hline \multirow{2}{*}{$\begin{array}{l}\text { Age } \\
\text { (year) }\end{array}$} & \multicolumn{3}{|c|}{ Boys } & \multicolumn{3}{|c|}{ Girls } \\
\hline & $\begin{array}{c}\text { Non- } \\
\text { immunized }\end{array}$ & $\begin{array}{l}\text { Partially } \\
\text { immunized }\end{array}$ & $\begin{array}{c}\text { Fully } \\
\text { immunized }\end{array}$ & $\begin{array}{c}\text { Non- } \\
\text { immunized }\end{array}$ & $\begin{array}{l}\text { Partially } \\
\text { immunized }\end{array}$ & $\begin{array}{c}\text { Fully } \\
\text { immunized }\end{array}$ \\
\hline $1-2$ & 27 & 38 & 132 & 32 & 40 & 127 \\
\hline $2-3$ & 40 & 37 & 108 & 28 & 51 & 123 \\
\hline $3-4$ & 42 & 41 & 144 & 29 & 43 & 134 \\
\hline $4-5$ & 35 & 42 & 116 & 25 & 49 & 111 \\
\hline $5-7$ & 72 & 73 & 201 & 67 & 61 & 196 \\
\hline Total & $\begin{array}{l}216 \\
(18.82)\end{array}$ & $\begin{array}{l}231 \\
(20.12)\end{array}$ & $\begin{array}{l}701 \\
(61.06)\end{array}$ & $\begin{array}{l}181 \\
(16.22)\end{array}$ & $\begin{array}{l}244 \\
(21.86)\end{array}$ & $\begin{array}{l}691 \\
(61.92)\end{array}$ \\
\hline
\end{tabular}


Table 5: Immunization coverage of Polio.

\begin{tabular}{|c|c|c|c|c|c|c|}
\hline \multirow{2}{*}{$\begin{array}{l}\text { Age } \\
\text { (year) }\end{array}$} & \multicolumn{3}{|c|}{ Boys } & \multicolumn{3}{|c|}{ Girls } \\
\hline & $\begin{array}{c}\text { Non- } \\
\text { immunized }\end{array}$ & $\begin{array}{l}\text { Partially } \\
\text { immunized }\end{array}$ & $\begin{array}{c}\text { Fully } \\
\text { immunized }\end{array}$ & $\begin{array}{c}\text { Non- } \\
\text { immunized }\end{array}$ & $\begin{array}{l}\text { Partially } \\
\text { immunized }\end{array}$ & $\begin{array}{c}\text { Fully } \\
\text { immunized }\end{array}$ \\
\hline $1-2$ & 22 & 44 & 131 & 32 & 40 & 127 \\
\hline $2-3$ & 40 & 37 & 108 & 28 & 49 & 125 \\
\hline $3-4$ & 38 & 43 & 146 & 30 & 37 & 139 \\
\hline $4-5$ & 35 & 42 & 116 & 29 & 41 & 115 \\
\hline $5-7$ & 70 & 73 & 203 & 65 & 60 & 199 \\
\hline Total & $\begin{array}{l}205 \\
(17.86 \%)\end{array}$ & $\begin{array}{l}239 \\
(20.82 \%)\end{array}$ & $\begin{array}{l}704 \\
(61.32 \%)\end{array}$ & $\begin{array}{l}184 \\
(16.49 \%)\end{array}$ & $\begin{array}{l}227 \\
(20.34 \%)\end{array}$ & $\begin{array}{l}705 \\
(63.17 \%)\end{array}$ \\
\hline
\end{tabular}

under the study area is much less than the coverage of NE states coverage $(67.6 \%)$ studied by Yadav and Singh (2004) and National coverage DPT $(80.8 \%)$ studied by Singh and Yadav (2000).

We found that $17.86 \%$ boys and $16.49 \%$ girls were not received polio vaccine. $20.82 \%$ boys and $20.34 \%$ girls were partially immunized with polio vaccine (Table 5). So, the added number of these two is $38.68 \%$ for boys and $36.83 \%$ for girls. $61.32 \%$ boys and $63.17 \%$ girls were fully immunized with polio vaccine. The coverage level of polio vaccine at study area of the two districts is much less than the NE states coverage $(67.7 \%)$ studied by Yadav and Singh (2004) and national coverage $(81 \%)$ studied by Singh and Yadav (2000).

From the measles (Table 6) we found that $46.25 \%$ boys and $47.76 \%$ girls were not immunized with measles vaccine. The remaining $53.75 \%$ boys

Table 6: Immunization status of measles.

\begin{tabular}{lccllc}
\hline \multirow{2}{*}{$\begin{array}{l}\text { Age } \\
\text { (year) }\end{array}$} & \multicolumn{2}{c}{ Boys } & & \multicolumn{2}{c}{ Girls } \\
\cline { 2 - 3 } \cline { 5 - 6 } & $\begin{array}{c}\text { Non- } \\
\text { immunized }\end{array}$ & $\begin{array}{c}\text { Immu- } \\
\text { nized }\end{array}$ & & $\begin{array}{c}\text { Non- } \\
\text { immunized }\end{array}$ & $\begin{array}{c}\text { Immu- } \\
\text { nized }\end{array}$ \\
\cline { 2 - 3 } \cline { 5 - 6 } & No. & No. & & No. & No. \\
\hline $1-2$ & 79 & 118 & & 89 & 110 \\
$2-3$ & 75 & 110 & & 96 & 106 \\
$3-4$ & 111 & 116 & & 99 & 107 \\
$4-5$ & 94 & 99 & & 86 & 99 \\
$5-7$ & 172 & 174 & & 163 & 161 \\
\hline Total & 531 & 617 & & 533 & 583 \\
& $(46.25 \%)$ & $(53.75 \%)$ & $(47.76 \%)$ & $(52.24 \%)$
\end{tabular}

and $52.24 \%$ girls were fully immunized with measles. The coverage is quiet similar to North East states coverage $(54.3 \%)$ studied by Yadav and Singh (2004) but it is much less than the national coverage $(66.5 \%)$ studied by Singh and Yadav (2000). A study in Naxalbari indicated the measles coverage is $51.2 \%$ reported by Mukherjee et al. (1990), which is also less than the national coverage.

We collected the data of child immunization mostly with the help of immunization card. Table 7 focused the number and percent of the children produced card, not produced card, lost card or without card. The parents of about $49.25 \%$ children were produced immunization card, which is not a good percent. The added value of lost card and without immunization card holders children's is $20.58 \%$.

The parents were placed in a four scored table to know the knowledge about child immunization

Table 8: Knowledge about vaccine on the basis of 4 (four) point score.

\begin{tabular}{lrrrrr}
\hline \multirow{2}{*}{ Scores } & \multicolumn{2}{c}{ Father } & & \multicolumn{2}{c}{ Mother } \\
\cline { 2 - 3 } & No. & \multicolumn{1}{c}{$\%$} & & No. & $\%$ \\
\hline 0 & 374 & 57.09 & & 677 & 47.48 \\
$0.25-1$ & 202 & 30.84 & & 473 & 33.17 \\
$1.25-2$ & 59 & 9.00 & & 178 & 12.48 \\
$2.25-3$ & 13 & 1.98 & 75 & 5.26 \\
$3.25-4$ & 07 & 1.06 & 23 & 1.61 \\
\hline Total & 655 & & 1426 & \\
\hline
\end{tabular}

Table 7: Immunization card.

\begin{tabular}{|c|c|c|c|c|c|c|c|c|}
\hline \multirow[t]{2}{*}{ Age (year) } & \multicolumn{2}{|c|}{ Card produced } & \multicolumn{2}{|c|}{$\begin{array}{c}\text { Card present } \\
\text { but not produced }\end{array}$} & \multicolumn{2}{|c|}{ Card lost } & \multicolumn{2}{|c|}{ Without card } \\
\hline & No. & $\%$ & No. & $\%$ & No. & $\%$ & No. & $\%$ \\
\hline $1-2$ & 244 & 61.62 & 109 & 27.53 & 22 & 5.55 & 21 & 5.30 \\
\hline $2-3$ & 221 & 57.10 & 93 & 24.03 & 39 & 10.08 & 34 & 8.79 \\
\hline $3-4$ & 208 & 48.04 & 132 & 30.48 & 48 & 11.09 & 45 & 10.39 \\
\hline $4-5$ & 189 & 50.00 & 107 & 28.31 & 52 & 13.76 & 30 & 7.93 \\
\hline $5-7$ & 253 & 37.76 & 242 & 36.12 & 126 & 18.81 & 49 & 7.31 \\
\hline Total & 1115 & 49.25 & 683 & 30.17 & 287 & 12.67 & 179 & 7.91 \\
\hline
\end{tabular}


(Table 8). We found that $57.09 \%$ father and $47.48 \%$ mother got 0 score. Only $1.06 \%$ father and $1.61 \%$ mother have got score 4 . The added value of 0 and 1 score of father is $87.93 \%$ and of mother is $80.65 \%$. We also found that the parents got scored because most of them know the name of the vaccines. So, the knowledge about immunization of the parents is very poor.

The study indicated that the knowledge about immunization is directly related to education (Table 9), which has been supported by Streatgelt (1990). Parents with higher education got the higher score, the illiterate parents failed to achieve higher scores like 3 and 4. Father with class VIII and above education achieved the highest score. More number of mother with class VIII and above education achieved highest score.

We found 552 boys were fully immunized, 394 were partially immunized and 202 were non immunized. Similarly 551 girls were fully immunized, 361 were partially immunized and 204 were non immunized. In this study it has been focused that the negligence is the important factor out of six factors considered here for non-immunization and dropouts (Table 10).

The children of the rural belt with poor socio economic background are suffering from different types of diseases (Table 11). Children usually suffer from high fever, common cold and diarrhoea. We included the children those are suffering from high fever, common cold and diarrhoea, 3 times or more in a year. We found $53.58 \%$ children suffering from high fever, $66.03 \%$ suffering from common cold and $61.26 \%$ suffering from diarrhoea. Malaria and jaundice were two major diseases of the rural belt. $28.75 \%$ children were suffering from malaria and $32.29 \%$ children were suffering from jaundice.

Mortality is the good indicator of immunization and health status of the children. Out of 234 dead children 110 were boys and 124 were girls. We found that the cause of 58 dead was unknown, 49 child died in diarrhoea (Table 12).

A study in some blocks of West Bengal indicated that $45.9 \%$ children were fully immunized studied by Mukherjee et al. (1990), they

Table 9: Literacy and immunization knowledge.

\begin{tabular}{|c|c|c|c|c|c|c|c|c|c|c|c|c|}
\hline \multirow[t]{2}{*}{ Literacy } & \multirow[t]{2}{*}{ No. } & \multicolumn{5}{|c|}{ Scores of Father } & \multirow[t]{2}{*}{ No. } & \multicolumn{5}{|c|}{ Scores of Mother } \\
\hline & & 0 & 1 & 2 & 3 & 4 & & 0 & 1 & 2 & 3 & 4 \\
\hline Illiterate & 170 & 158 & 11 & 1 & - & - & 442 & 423 & 16 & 3 & - & - \\
\hline Primary & 259 & 153 & 98 & 5 & 2 & - & 520 & 187 & 304 & 20 & 8 & 1 \\
\hline Class V-VIII & 138 & 54 & 66 & 17 & 2 & - & 228 & 60 & 92 & 62 & 13 & 1 \\
\hline Class IX-X & 69 & 9 & 27 & 28 & 3 & 2 & 178 & 7 & 59 & 87 & 17 & 8 \\
\hline Above & $13+6$ & - & - & 8 & 6 & 5 & $43+15$ & - & 2 & 6 & 37 & 13 \\
\hline
\end{tabular}

Table 10: Reasons for non-immunization and dropouts.

\begin{tabular}{|c|c|c|c|c|c|c|c|c|}
\hline \multirow[t]{3}{*}{ Reasons } & \multicolumn{4}{|c|}{ Partially immunized } & \multicolumn{4}{|c|}{ Non-Immunized } \\
\hline & \multicolumn{2}{|c|}{ Boys } & \multicolumn{2}{|c|}{ Girls } & \multicolumn{2}{|c|}{ Boys } & \multicolumn{2}{|c|}{ Girls } \\
\hline & No. & $\%$ & No. & $\%$ & No. & $\%$ & No. & $\%$ \\
\hline 1. Children went to other place & 59 & 14.97 & 43 & 11.91 & 18 & 8.91 & 27 & 13.24 \\
\hline 2. Negligence & 102 & 25.89 & 87 & 24.10 & 63 & 31.19 & 71 & 34.80 \\
\hline 3. Unfaith to vaccine & 47 & 11.93 & 36 & 9.97 & 16 & 7.92 & 22 & 10.78 \\
\hline 4. Guardians busy & 79 & 20.05 & 94 & 26.04 & 51 & 25.25 & 37 & 18.14 \\
\hline 5. Ignorance & 32 & 8.12 & 47 & 13.02 & 28 & 13.86 & 12 & 5.88 \\
\hline 6. Unwell & 75 & 19.04 & 54 & 14.96 & 26 & 12.87 & 35 & 17.16 \\
\hline
\end{tabular}

Table 11: Disease susceptibility of the children.

\begin{tabular}{|c|c|c|c|c|c|c|c|c|c|c|c|c|}
\hline \multirow[t]{3}{*}{ Diseases } & \multicolumn{10}{|c|}{ Age } & \multirow{2}{*}{\multicolumn{2}{|c|}{ Total }} \\
\hline & \multicolumn{2}{|c|}{ 1-2 yrs } & \multicolumn{2}{|c|}{$2-3 y r s$} & \multicolumn{2}{|c|}{ 3-4 yrs } & \multicolumn{2}{|c|}{ 4-5 yrs } & \multicolumn{2}{|c|}{ 5-7 yrs } & & \\
\hline & No. & $\%$ & No. & $\%$ & No. & $\%$ & No. & $\%$ & No. & $\%$ & No. & $\%$ \\
\hline High Fever* & 242 & 61.11 & 248 & 64.08 & 321 & 74.13 & 198 & 52.38 & 204 & 30.45 & 1213 & 53.58 \\
\hline Common Cold $*$ & 267 & 67.42 & 296 & 76.49 & 208 & 48.03 & 282 & 74.6 & 442 & 65.97 & 1495 & 66.03 \\
\hline Diarrhoea* & 228 & 57.58 & 257 & 66.41 & 276 & 63.74 & 270 & 71.42 & 356 & 53.13 & 1387 & 61.26 \\
\hline Malaria** & 84 & 22.47 & 73 & 18.86 & 114 & 26.32 & 203 & 53.70 & 277 & 41.34 & 651 & 28.75 \\
\hline Jaundice $* *$ & 100 & 25.25 & 89 & 22.99 & 135 & 31.17 & 168 & 44.44 & 239 & 35.67 & 731 & 32.29 \\
\hline
\end{tabular}

$*=$ Three times or more in a year $* *=$ At least once in a year 
Table 12: Mortality.

\begin{tabular}{lrrr}
\hline Reason & Boys & Girls & Total \\
\hline Unknown reason & 33 & 32 & 65 \\
Fever & 17 & 19 & 36 \\
Jaundice & 15 & 13 & 28 \\
Diarrhea & 21 & 28 & 49 \\
Malaria & 8 & 12 & 20 \\
Pneumonia & 16 & 20 & 36 \\
\hline Total & 110 & 124 & 234 \\
\hline
\end{tabular}

also reported that the $19.2 \%$ children remain nonimmunized because of ignorance.

\section{DISCUSSION}

The children of one to seven years of age of two districts of North Bengal are not receiving proper immunization schedule. The coverage for the different vaccines is low studied by Singh and Yadav (2000). The parents are illiterate and are not serious about keeping the immunization card. The knowledge of the parents about immunization is very poor and the literacy of the parents is also poor. So, the parents are not serious about immunization and we found that negligence is the major cause for non immunization and guardian engagement in other work is the major cause for partial immunization. The parents fell to take the initiative for the treatment of diseases of child because of poorness. So, the child mortality in this area is high. Our results are also consistent with the reports of Elliott and Farmer (2006) where literacy is considered as one of the factors for full immunization. Similarly the cross sectional survey by Sharma et al. (2009) in Surat also focused the full immunization is of $25 \%$ due to poor education. One study in Nigeria shows that poor immunization is the cause of increased child mortality studied by Nwoqu et al. (2008). An important finding in this survey was that a significant percentage of parents in study area do not believe the beneficial effect of vaccine indicating an immediate need to create common awareness regarding UIP. The findings are sending a clear message that the child immuni-zation needs to be more attention in poor and illiterate areas so that all the children get proper immunization in the prescribed date. The awareness programme may be implemented at such rural belts by government and non government sectors so that parents may change their attitude and practice for better immunization for their children.

\section{CONCLUSION}

From the results of this survey it may be concluded that at rural belt of Darjeeling and Jalpaiguri districts the child immunization coverage is not so good and there is a scope for improvement in this regard. Information, education and communication (IEC) activities should be revitalized at such belts to increase the awareness and to improve their practices and attitudes for the full implementation of Universal Immunization Programme (UIP). Supervision of ongoing UIP, reorientation of health services may be considered as key components. Side by side sustain routine immunization coverage should be followed in order to touch the untouched.

\section{ACKNOWLEDGEMENT}

Authors are gratefully acknowledged the local people, panchayet members, tea garden managers of the study area.

\section{REFERENCES}

Dalal A, Silveira MP 2005. Immunization Status of Children in Goa. Ind Pediatr, 42: 401-402.

Elliott C, Farmer K 2006. Immunization status of children under 7 years in the Vikas Nagar area, North India. Child Care Health Dev, 32: 415-421.

Grachev VP 1994. Long term use of oral polio vaccine from sabin strains in the Soviet Union. Rev Infect Dis, 6: 321-322.

Lodha R, Dash NR, Kapil A, Kabra SK 2000. Diphtheria in urban slums in North India. Lancet, 355: 204.

Ministry of Health and Family Welfare, 1999. Evaluation of Routine Immunization 1997-1998. New Delhi: Department of Family Welfare, MOHFW.

Mukherjee B, Ray SK, Kar M, Madal A, Mitra J, Biswas R 1990.Coverage Evaluation Surveys amongst children's in some blocks of West Bengal. Ind J Pub Health, 34: 209-214.

Nwoqu R, Larson JS, Kim MS 2008. Reducing child mortility in Nigeria: A case study of immunization and systemic factors. Soc Sci Med, 68: 161-164.

Pulickal AS, Fernandez GV 2007. Comparison of the prevalence of tuberculosis infection in BCG vaccinated versus non vaccinated school age children. Ind Pediatr, 44: 344-347.

Sharma R, Desai VK, Kavishvar A 2009. Assessment of immu-nization status in the slums of Surat by 15 clusters multi indicators cluster survey technique. Ind J Commu Med, 34: 152 -155.

Singh P, Yadav RJ 2000. Immunization status of children in India. Ind Paediatr, 37: 1194-1199.

Streatgelt K, Singarimbun M, Diamand I 1990. Maternal education and immunization. Demography, 27: 447455 .

Yadav RJ, Singh P 2004. Immunization status of children and mothers in the state of Madhya Pradesh. Ind $J$ Coтmu Med, 29: 147-148. 